\title{
ON THE GENUS SUNIUS STEPHENS, 1829 OF TURKEY VII. TWO NEW MICROPTEROUS SPECIES FROM SOUTHERN ANATOLIA (COLEOPTERA: STAPHYLINIDAE, PAEDERINAE)
}

\author{
SinAn AnLaş \\ Manisa Celal Bayar University, Alaşehir Vocational School, TR-45600, Alaşehir, Manisa, Turkey \\ E-mail: sinan.anlas@gmail.com; https://orcid.org/0000-0001-7059-5677
}

Two new species of Sunius Stephens (Coleoptera: Staphylinidae, Paederinae) from southern Anatolia are described, illustrated and distinguished from related congeners: Sunius orgeli sp. n. (Niğde) and Sunius cercii sp. n. (Konya and Karaman). Some specimens of the new species were collected with subterranean pitfall traps in the mesovoid shallow substratum. Additional records of three species of Sunius from Turkey are reported. The genus is now represented in Turkey by 41 species, 37 of them are endemic.

Keywords: Coleoptera, Staphylinidae, Paederinae, Sunius, Turkey, new species.

\section{INTRODUCTION}

The genus Sunius contains 140 species in the Palaearctic region, and 127 of these are known from the Western Palaearctic region and Middle Asia (AssING 2008, 2017, SснÜLKe \& SMETANa 2015). Up to the present, 39 species of the genus Sunius have been recorded from Turkey (ANLAş 2018b), representing approximately $1 / 3$ of the Palaearctic Sunius fauna. Nevertheless, it is still an underestimate of the Sunius diversity of the country. Among Turkish Sunius there are 35 montane endemics restricted in their distribution to particular mountain ranges, like the Taurus and mountains of western Anatolia.

Two undescribed species apparently representing local montane endemics of this genus, were recently collected in the Taurus mountain range in southern Anatolia. These two species are here described under the names Sunius orgeli sp. n. (Niğde province) and S. cercii sp. n. (Konya and Karaman provinces). Some specimens of the new species were collected with a subterranean pitfall trap in the mesovoid shallow substratum (MSS). This shows that the MSS trap method can be used to collect Sunius specimens. The genus is now represented in Turkey by 41 species, 37 of which are endemic.

\section{MATERIAL AND METHODS}

The present paper is based on material collected during a recent field study in the southern Anatolia, in Spring 2018. The morphological studies were conducted using a Stemi 508 microscope (Zeiss, Germany). Photographs of the habitus, forebody and aedeagus of the studied species were taken with a digital camera (Zeiss Axiocam ERC5s). All photo- 
graphs were edited with the Helicon Focus v. 6, and Coreldraw X5 software. The map was made using the software Google Earth Pro (2019).

Nomenclature of the terminalia and the style of the description follow Assing (2008). Head length was measured from the anterior margin of the frons to the posterior margin of the head, length of the pronotum was measured along the median line, elytral length was measured at the suture from the apex of the scutellum to the posterior margin of the elytra. The length of the median lobe of the aedeagus was measured from the apex of the ventral process to the base of the capsule. The material referred to in this study is stored in the Alaşehir Zoological Museum, Manisa, Turkey (AZMM) and in Natural History Museum, Oslo, Norway (NHMO).

\section{TAXONOMY}

\section{Sunius orgeli sp. $n$.}

(Figs 1-8, 17)

Type material - Holotype: TURKEY: $\widehat{\jmath}$, “TR. Niğde, Bor, Halaç 8 km NE, Pozantı

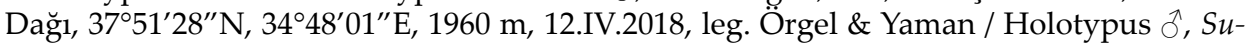
nius orgeli sp. n. det. S. Anlaş 2019" (AZMM). Paratypes: $3{ }^{\lambda}, 2$, ¡ 1 1 , by MSS traps) (AZMM, NHMO).

Description - Habitus as in Fig. 1. Small species, body length 2.6-2.8 mm. Colouration: forebody uniformly reddish or reddish yellow; elytra slightly darker, abdomen dark brown, with the paratergites paler brown; legs yellowish-brown; antennae reddish-brown.

Head weakly oblong (Figs 1-2), approximately 1.05-1.10 times as long as wide; lateral margins in dorsal view straight and slightly diverging posteriad; punctation coarse, irregular, and sparse, in lateral area slightly denser than in medio-dorsal area; pubescence short and brownish but not dense; microsculpture absent, eyes very small (Fig. 2), slightly projecting from lateral outline of head, postocular region in dorsal view approximately 2.5-3.0 times as long as eyes. Antennae moderately slender, approximately $0.70-0.75 \mathrm{~mm}$ long.

Pronotum approximately 0.90 times as wide as head (Figs 1-2), and about 1.05 times as long as wide; lateral margins subparallel and diverging posteriad in dorsal view; microsculpture absent; punctation somewhat coarser, medial line impunctate, slightly smaller and denser than that of head; pubescence similar to that of head, but slightly denser and well-defined than that; lateral margin of pronotum with several brown blackish setae.

Elytra approximately as wide as pronotum (Figs 1-2) and at suture about $0.75-0.80$ times as long as pronotum; punctation weakly granulose, and finer and denser than that of pronotum and head; microsculpture invisible; pubescence black or dark brown, more distinct than that of head and pronotum. Hind wings completely reduced.

Abdomen wider than elytra (Fig. 1), approximately 1.05-1.10 times as wide as elytra, widest at segments VI-VII; punctation dense and fine; microsculpture shallow; pubescence brown and sparse; posterior margin of tergite VII without palisade fringe.

$\delta$ : sternite VII in posterior median area slightly concave and without modified setae, (Fig. 3); posterior margin of sternite VIII with relatively wide emargination, posteriorly with median cluster of very weak pubescence, with smaller tubercule (Fig. 4); aedeagus approximately $0.34-0.37 \mathrm{~mm}$ long, shaped as in Figs $5-8$, with apical portion of ventral process dentate, slender and longer in lateral view; internal sac with a series of four mixed large and small spines. 

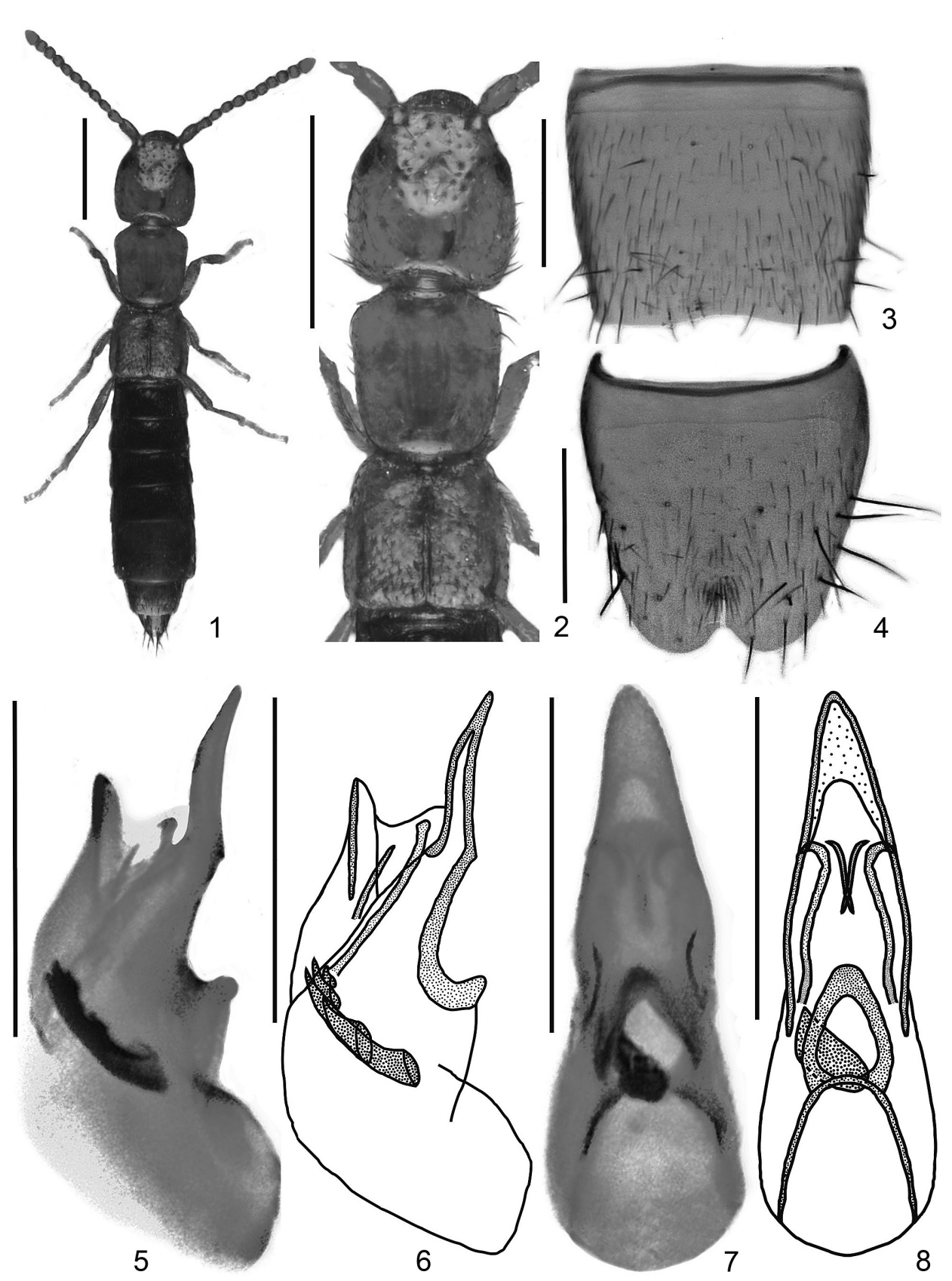

Figs 1-8. Details of Sunius orgeli sp. n.: 1 = habitus; $2=$ forebody; $3=$ male sternite VII, $4=$ male sternite VIII, 5-6 = aedeagus, lateral view, $7-8=$ aedeagus, ventral view. Scale bars: $0.5 \mathrm{~mm}(1-2) ; 0.2 \mathrm{~mm}(3-8)$ 
Etymology - The species is dedicated to Semih Örgel, Manisa, who collected some of the type specimens of this new species.

Comparative notes - The species is distinguished from all its congeners by the male sexual characters, especially by the ventral process of the aedeagus, which is of different shape, particularly in lateral view. Based on the similar morphology of the male primary and secondary sexual characters, the new species is closely related to S. tauricus Anlaş, 2018 (Karaman, Yüğlük Hill), S. tuberiventris Assing, 2001 (Mersin, Sertavul pass) S. wunderlei Assing, 2001 (Mersin, Gülnar) and S. balkarensis Assing, 2001 (Mersin, Çamliyayla). The new species is readily separated from these species as follows:

From $S$. tauricus by the presence of a tubercule on abdominal sternite VIII (in S. tauricus: sternite VIII in posterior median area without tubercle), by the slender ventral process of the aedeagus in lateral view, by the different shape and the series of four spines in the internal sac (in S. tauricus: internal sac with a series of six mixed large and small spines).

From $S$. tuberiventris by the slender and more flat ventral process of the aedeagus in lateral view, by the more distinct dentate apical portion of the ventral process in lateral view; by the narrower and shorter ventral process of the aedeagus in ventral view, by the differently shaped spines in the internal sac (in S. tuberiventris: internal sac with row of four relatively small spines).

From S. wunderlei by the more flat ventral process of the aedeagus in lateral view, by the more distinct dentate apical portion of the ventral process in lateral view; by the narrower ventral process of the aedeagus in ventral view, by the shorter pubescence on the posterior median tubercle in sternite VIII.

From S. balkarensis by the slender and longer ventral process of the aedeagus in lateral view; by the more distinct dentate apical portion of the ventral process in lateral view; by the narrower and longer ventral process of the aedeagus in ventral view.

For descriptions, illustrations and distributions of these species see AssING (2001), ANLAŞ (2018a) and Figure 17.

Distribution and bionomics - The new species was collected on the Pozantı Mountain, in Niğde province. The specimens were found under stones and some of them were collected with a subterranean pitfall trap in a calcareous grassland at an altitude of $1960 \mathrm{~m}$.

\section{Sunius cercii sp. $\mathrm{n}$. \\ (Figs 9-16, 17)}

Type material - Holotype: TURKEY: ${ }^{\lambda}$, “TR. Konya, Hadim, Çiftepınar 5 km S, 36 58'21"N, 3241'05”'E, 1990 m, 03.V.2018, leg. Örgel \& Yaman / Holotypus ồ, Sunius cercii sp. n. det. S. Anlaş 2019" (AZMM). Paratypes: 3 제, 11 , same data as holotype (AZMM, 


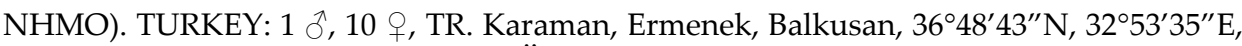
1890 m, 02.V.2018, by MSS traps, leg. Örgel \& Yaman (AZMM, NHMO).

Etymology - The specific epithet honors Barış Çerci, Ankara, a specialist on Heteroptera, who has carried out important entomological researches in Turkey.

Description - Habitus as in Fig. 9. Small species, body length $2.4-2.7 \mathrm{~mm}$, similar to S. orgeli, but distinguished as follows:

Head oblong (Figs 9-10), approximately 1.20-1.25 times as long as wide; antennae approximately $0.68-0.74 \mathrm{~mm}$ long. Pronotum approximately 0.95 times as wide as head (Figs 9-10). Elytra (Figs 9-10) slightly (approximately 1.05 times) wider than pronotum and at suture about $0.70-0.75$ times as long as pronotum. Abdomen approximately as wide as elytra (Fig. 9).

$\delta$ : sternite VII in posterior median area very slightly concave and without modified setae, (Fig. 11); posterior margin of sternite VIII with relatively wide emargination, posteriorly with median cluster of very weak pubescence, without tubercule (Fig. 12); aedeagus approximately $0.32-0.35 \mathrm{~mm}$ long, shaped as in Figs 13-16, with apical portion of ventral process dentate, with broader and stouter ventral process in lateral view; internal sac with a series of six mixed large and small spines.

Comparative notes - The species can be distinguished from all its congeners by the different shape of the ventral process of the aedeagus and by the shape of the spines of the internal sac. Based on the similar morphology of the male primary and secondary sexual characters, the new species is closely related to S. yamani Anlaş, 2018 (Konya, Derebucak), S. ulcerosus Assing, 2011 (Isparta, Dedegöl Mountains) and S. brachati Assing, 2003 (Antalya, Finike). The new species is readily separated from these species as follows:

From S. yamani by the slender ventral process of the aedeagus in lateral view, by the different shape and the series of six uniformly sized spines in the internal sac (in S. yamani: internal sac with a series of five mixed large and small spines).

From S. ulcerosus by the absence of a tubercule on abdominal sternite VIII (in S. ulcerosus: sternite VIII posteriorly with a median subcircular protuberance), by the broader and stouter ventral process of the aedeagus in lateral view, by the differently shaped spines in the internal sac (in S. ulcerosus: internal sac with a row of approximately 5-7 distinctly sclerotised and moderately long spines).

From S. brachati by the absence of a tubercule on abdominal sternite VIII (in S. brachati: small tubercle on sternite VIII), by the broader and stouter ventral process of the aedeagus in lateral view, by the presence of sclerotized spines in the internal sac.

For descriptions, illustrations and distributions of these species see AssING $(2003,2011)$, ANLAş (2018b) and Figure 17.

Distribution and bionomics - The species was found at two localities from Konya (Hadim) and Karaman (Ermenek). The specimens were found under stones and sifted from grass roots between limestone gravel on a pas- 

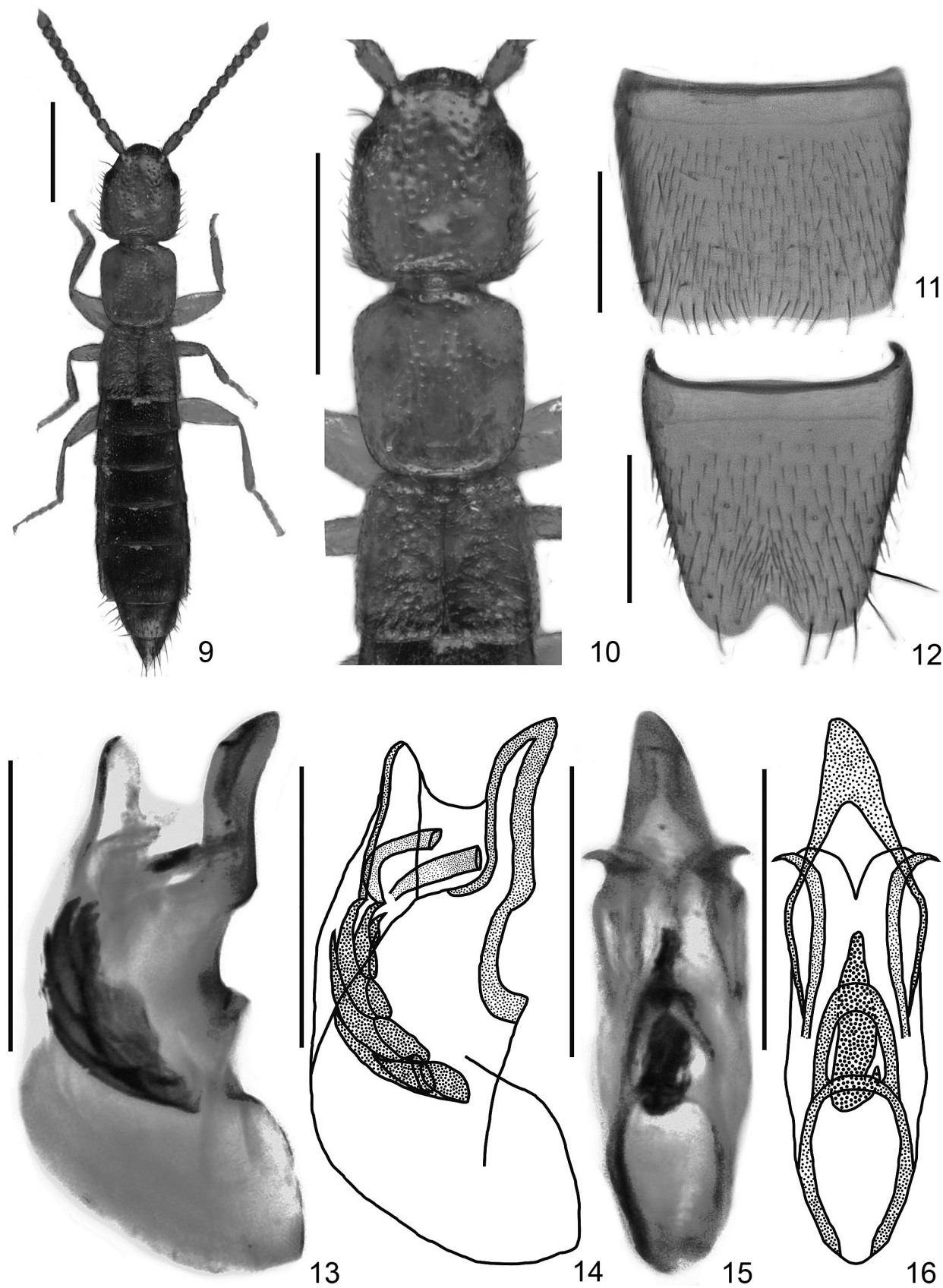

12

Figs 9-16. Details of Sunius cercii sp. n.: 9 = habitus; 10 = forebody, $11=$ male sternite VII, 12 = male sternite VIII, 13-14 = aedeagus, lateral view; $15-16$ = aedeagus, ventral view. Scale bars: $0.5 \mathrm{~mm}(1-2) ; 0.2 \mathrm{~mm}$ (3-8) 
ture with shrubs, at altitudes of 1890 and $1990 \mathrm{~m}$. Some specimens were collected with a MSS trap in a rocky steep slope in the subalpine zone.

\section{ADDITIONAL RECORDS}

\section{Sunius balkarensis Assing, 2001}

Material examined - TURKEY: Niğde: 2 ${ }^{\lambda}, 4$, 13.IV.2018, Ulukışla, Kılan 5 km SW, Güney Dağ ${ }^{1}, 37^{\circ} 26^{\prime} 42^{\prime \prime} \mathrm{N}, 34^{\circ} 25^{\prime} 55^{\prime \prime} \mathrm{E}, 1960$ m, leg. Örgel \& Yaman (AZMM). Konya: 5 §’, 17

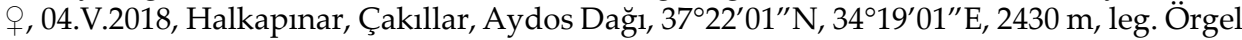
\& Yaman (AZMM).

Remark - This species has so far only been known from the Bolkar Mountains, Mersin province, in Southern Turkey (Assing 2001; Anlaş 2018b).

\section{Sunius tauricus Anlaş, 2018}

Material examined - TURKEY: Karaman: 3 ๙ , 5 \& , 30.X.2017 and 03.V.2018, Ayranc1,

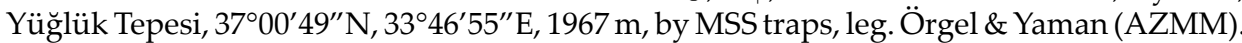

Remark - The recently described species is only known from Yüğlük Hill, Karaman province, in Southern Turkey (Anlaş 2018a).

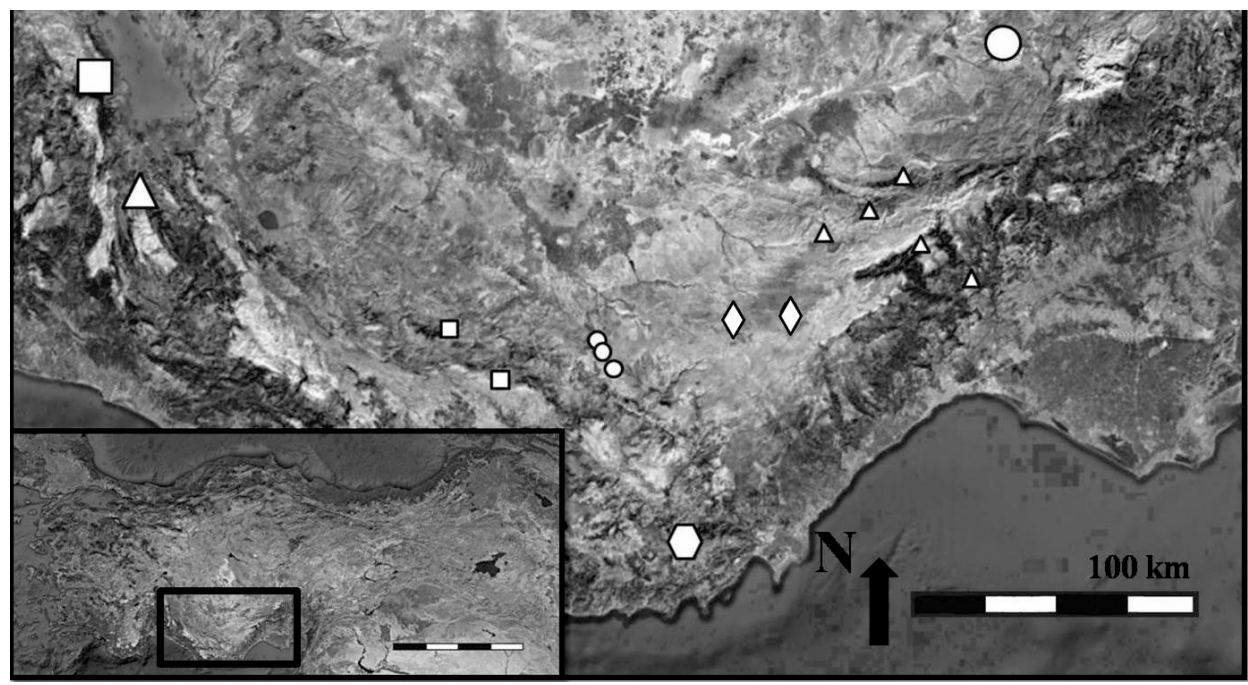

Fig. 17. Distributions of Sunius ulcerosus Assing (large square), S. yamani Anlaş (large triangle), S. cercii sp. n. (small squares), S. tuberiventris Assing (small circles), S. wunderlei Assing (Hexagon), S. tauricus Anlaş (diamonds), S. balkarensis Assing (small triangles), S. orgeli sp. n. (large circle) 


\section{Sunius khnzoriani (Coiffait, 1970)}

Material examined - TURKEY: Kayseri: 2 §, 2 ㅇ, 05.VI.2016-02.XI.2017, Kayseri, Yahyalı, Aladağlar, 37 $56^{\prime} 02^{\prime \prime} \mathrm{N} 35^{\circ} 15^{\prime} 23^{\prime \prime} \mathrm{E}, 2700 \mathrm{~m}$, by MSS traps (AZMM). Sivas: $1 \hat{0}$,

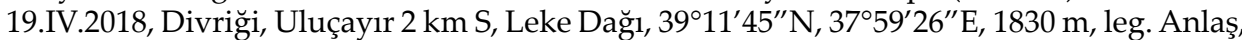
Örgel \& Yaman (AZMM). 1 §̊, 16.IV.2018, Koyulhisar, 40²3’54”N, 3758’03”E, 1930 m, leg. Anlaş, Örgel \& Yaman (AZMM).

Remark - This species was known from Adiyaman, Antalya, Bitlis, Kars and Mersin provinces in Turkey (ANLAş 2009), and here reported for the first time from central Anatolia.

Acknowledgements - I am most grateful to Semih Örgel and Serkan Yaman for making their staphylinid collections available to me and also thanks to Alfred Newton (Chicago) for revision of the English manuscript. This study was supported by the Scientific and Technological Research Council of Turkey (TUBITAK, project no. 215Z080).

\section{REFERENCES}

Anlaş, S. (2009): Distributional checklist of the Staphlinidae (Coleoptera) of Turkey, with new and additional records. - Linzer biologische Beiträge 41: 215-342.

Anlaş, S. (2018a): On the genus Sunius Stephens 1829 of Turkey. V. A new micropterous species from central southern Anatolia, with additional records from the western Mediterranean region (Coleoptera: Staphylinidae: Paederinae). - Revue Suisse de Zoologie 125: 17-20. https://doi.org/10.5281/zenodo.1196005

Anlaş, S. (2018b): On the genus Sunius Stephens 1829 of Turkey. VI. A new micropterous species and distribution of the genus (Coleoptera: Staphylinidae: Paederinae). - Zoology in the Middle East 64: 68-74. https://doi.org/10.1080/09397140.2017.1401307

Assing, V. (2001): On the Turkish species of Sunius Curtis 1829 (Coleoptera: Staphylinidae, Paederinae). -Linzer biologische Beiträge 33: 195-210.

Assing, V. (2003): New species and records of Staphylinidae from Turkey (Insecta: Coleoptera: Staphylinidae). - Entomologische Blätter 98 (2002): 153-177.

Assing, V. (2008): A revision of the Sunius species of the Western Palaearctic region and Middle Asia (Coleoptera: Staphylinidae: Paederinae). - Linzer biologische Beiträge 40: 5-135.

Assing, V. (2011): A revision of Palaearctic Sunius XIV. Three new species from Turkey and additional records (Coleoptera: Staphylinidae: Paederinae). - Linzer biologische Beiträge 43: 1159-1168.

Assing, V. (2017): A revision of Sunius XVI. Two new species from Iran and Iraq (Coleoptera: Staphylinidae: Paederinae). - Beiträge zur Entomologie (Contributions to Entomology) 67: 247-253. https://doi.org/10.21248/contrib.entomol.67.2.247-253

Schülke, M. \& Smetana, A. (2015): Staphylinidae. Pp. 304-1134. - In: Löвl, I. \& Löвl, D. (eds): Catalogue of Palaearctic Coleoptera. Vol. 2. Hydrophiloidea - Staphylinoidea. Revised and updated edition. - Leiden: Brill: xxvi + 1702 pp.

Received April 4, 2019, accepted June 18, 2019, published August 12, 2019 